\title{
Mostly Agree
}

National Cancer Institute

\section{Source}

National Cancer Institute. Mostly Agree. NCI Thesaurus. Code C103805.

A predominant feeling of concurrence. 